УДК-32(470.53)

DOI: 10.17072/2218-1067-2019-2-99-114

\title{
'BILBAO ON THE KAMA'? THE PERM CULTURAL PROJECT AND ITS CRITICS (PART 2)
}

\author{
Douglas Rogers \\ Yale University
}

\begin{abstract}
The following text is the second part of the Chapter 8 of Douglas Rogers's book The Depths of Russia: Oil, Power, and Culture after Socialism (Cornell University Press, 2015). The first part was published in the previous issue of the journal. The review of the book was published in the journal in 2017, No. 2. It is a prominent study of the 'Perm cultural project', one of the most important events in regional politics over the 2000s. We publish this text with the kind permission of the author and the publisher.
\end{abstract}

Keywords: cultural policy; art; oil; business and politics.

\section{Miracles and Heroes of Culture}

For Chirkunov's team, Cultural Revolution was less a domain of conceptions and plans than a domain of resolute action: any attempt to work through the existing, outmoded state cultural and bureaucratic channels was, they believed, doomed to fail. The Perm Cultural Project would thus need to rely in significant part on outside, contracted cultural managers and on seizing opportunities as they arose, without waiting for broad public consultation or the buy-in of the regional cultural intelligentsia. "Now is the time," Marat Gel'man was fond of saying, "for miracles and heroes" in the cultural sphere. Training a new generation of Perm- based cultural managers and producers was, to be sure, part of the plan, but that task would have to wait for later stages.

Indeed, the Perm Cultural Project team was acutely aware how rare and unusual was the vein of regional state funding that they had tapped. As Boris Mil'gram put it in one of his first major speeches on the issue, "I said earlier that we don't have any specific competitive advantage with other regions. That was a mistake! We do! We have a liberal-thinking governor, and that is already a resource." One of the lower-level members of his team voiced agreement in one of my conversations with her: "In addition to the stable financial situation [provided by regional budget allocations], we had a terrific administrative resource - the governor himself, who opened up an umbrella over all our cultural projects." But Oleg Chirkunov served at the pleasure of the president of the Russian Federation, and it was unlikely that the Perm Cultural Project would extend past his governorship; in fact, because the project was so closely identified with Chirkunov's office, his successor was likely to pursue a very different agenda for the region, just as Chirkunov had quickly distanced himself from Governor Trutnev's signature Capital of Civil Society campaign.

One primary hallmark of the Perm Cultural Project was thus the breakneck speed at which it unfolded. Public art installations sprang up overnight in central city spaces, sometimes entirely without warningsuch as the Power installation outside the Legislative Assembly building discussed in the introduction. ${ }^{1}$ One of the project managers brought in from outside of Perm recalled to me her shock at the pace:

Marat [Gel'man] said that we had very little time and would not work according to the schedules to which we were accustomed. I said that in the beginning we need to do research, plans, presentations, and so on. He said, "No, no, no, we are doing things differently: break ground first, then carry out the project, then dream."

It was, she reported, exhilarating to be freed of the normally sluggish bureaucracy. Although she and

\footnotetext{
${ }^{1}$ On the reception of some of the Perm Cultural Project's initiatives in the city, see especially Kruglova, 2013.

(C) Rogers D., 2019
} 
nearly everyone I spoke with agreed with Gel'man that this kind of pace was necessary in order to get anything accomplished at all, they also agreed that, in retrospect, this speed was an important reason that the Perm Cultural Project became so controversial.

\section{Culture Everywhere}

After its start at PERMM, the Perm Cultural Project played out across a great many cultural domains simultaneously. Among the most visible of its dimensions was a large, state-funded public art campaign, run out of the Perm Museum of Contemporary Art, with the explicit goal of moving contemporary art outside of the walls of the museum and directly into the squares and streets of Perm. In the introduction to the definitive catalog of the dozens of public art projects realized in Perm, Gel'man wrote of this effort in the context of Governor Chirkunov's long-term plans to develop the city of Perm into a modern, European city. Those urban redesign plans would take a long time to realize, "but people needed to see something concrete right now, an improvement in the present, not in some distant future. Real visible changes needed to start right away" (PERMM, 2011: 6-7). Through high profile installations such as Power, Red People, and Apple, as well as dozens of other smaller projects ranging from commissioned graffiti on crumbling Soviet-era facades to a series of painted angels that began to appear on balconies scattered throughout the city center, residents of Perm would immediately feel themselves connected to the transformation of urban culture and space in a new way. At the very least, they would be drawn into debates and discussions about what constituted art, the appropriate use of government funds and city spaces, or the meaning of the headless wooden red figure with a raised arm - was it voting? - that appeared perched atop the regional administration building. On this enthusiasm (or at least engagement) a new era of economic development could ride.

Projects like PERMM, the new Hammer Stage experimental theater, and public art installations were often cast in a language of urban rather than regional development, and so one of the questions that followed the Perm Cultural Project throughout its life was whether it was focused exclusively on the city of Perm or on the Perm region as a whole. The primary way in which the Perm Cultural Project did extend throughout the region was through increased regional funding for and coordination among festivals. According to Russia's official region numbering system - most commonly encountered on license plates - the Perm region was Russia's fifty-ninth. This number provided Mil'gram's Ministry of Culture with the inspiration for a new, region-wide program: Fifty-Nine Festivals for the Fifty-Ninth Region. All manner of festivals-from film festivals in Perm itself to new and revived district-level and local festivals up and down the Perm region - were eligible to be included. In 2010, this program featured twenty festivals billed as regional, an additional twenty-seven classified as intermunicipality collaborations, ten as interdistrict, and two as international. Only fifteen took place primarily in Perm, with the remainder spread throughout the smaller cities and districts of the Perm region.

These festivals were not only allocated new and ample funds for their own celebrations, but also were periodically invited to exhibitions of the entire Fifty- Nine Festivals project and other celebrations in Perm. Delegations from many of these festivals appeared onstage in succession, for instance, at the annual celebrations of City Day in Perm - held on the same June Day as the national Russia Day holiday. Under the auspices of the Perm Cultural Project, arrangements like this began to reconfigure the spatial organization of culture that had, since the beginning of Lukoil-Perm's Historical Cities of the Kama River Region festivals in 2001, been closely keyed to the geography of the oil industry. The entire region, that is, rather than primarily its constituent oil-producing districts, was transformed in the festival space. "The territory of creativity is expanding," proclaimed the Perm Cultural Project's promotional materials.

Public art installations and the Fifty-Nine Festivals movement - and many more dimensions of the Perm Cultural Project as well-came to a collective, spectacular crescendo in June 2012, when the Ministry of Culture sponsored a month-long "festival of festivals" called White Nights in Perm. An open poke at the legendary White Nights celebrations held during the longest summer days of the year in Saint Petersburg, White Nights in Perm was a month-long marathon of morning-to-evening cultural events designed to "create favorable conditions for living in and visiting Perm and the Perm region, and for the self-realization of individuals." White Nights in Perm was overwhelming by design. It boasted a total of 750 events; just one of its numerous constituent festivals, the Perm Alive festival of contemporary art, included 165 events in five days. The vast majority of the considerable bill for White Nights in Perm was picked up by the regional administration, with a substantial contribution from the Perm city budget as well. With the festival taking place on

\footnotetext{
1 “Polozhenie o Provedenii Festivalia 'Belye Nochi v Permi,'”, see www.permfest. com/about/polozjenie. January 23, 2012.
} 
the doorstep of its headquarters, and with many of its features in line with the company's own goals, LukoilPerm contributed around a fifth of the White Nights in Perm budget - 30 million rubles in 2012 — and many other local businesses signed up as sponsors as well. ${ }^{1}$

At the center of White Nights in Perm was a fenced-in Festival Village erected in front of the Regional Administration building on Perm's esplanade. Just over three hectares in size, the Festival Village included two small and one large out- door stages for concerts and other performances; numerous alleys for small shops and displays; two restaurants and two cafés; and a Festival Club for nearly fifty planned discussions and presentations. In order to cope with inevitable summer muddiness, boardwalk-style walkways were constructed to funnel crowds from space to space; they were repainted white nearly every night. Booths arrayed along- side these walkways provided spaces where folk artisans and other culture producers could display and sell their wares, and the grassy spaces between the walkways hosted small-scale performances and exhibitions, from clowns to blacksmiths. Everywhere there were nooks and crannies-many of them in two massive towers at one end of the Festival Village-where little exhibits or performances sprang up. Most stunningly to many observers, there was even a "festival beach": a large circular pool, suitable for dozens of children at a time, erected within a raised platform that could accommodate hundreds of sunbathers. Showers and changing rooms were located in a sandy area beneath.

For nearly a month, events of all sorts were scheduled for all hours of the day in the Festival Village. One day was devoted to folkloric performances by all the national and cultural groups represented in the Perm region; with each folklore troupe permitted only a few songs, the benches and walkways of the Festival Village were crowded with groups of mostly elderly women in costume awaiting their turns on stage. In a variation on the same take on the location of culture, another day featured a five-hour stretch in which the wedding celebrations of the national groups of the Perm region-from Chuvash to Russian to Tatar to Udmurt to Jewish - were showcased one after another. Many of these performers had experience with, and even owed their initial funding to, Lukoil-Perm's sponsorship of festivals and handicrafts earlier in the decade. In this context, however, those forms of corporation-sponsored cultural production were subsumed into the goals of the Perm Cultural Project. In the evenings, as buses carrying elderly folk- lore performers made their ways back to the region's rural districts, disc jockeys and pop groups from all over Russia took over the main stages. A delegation of more than 250 performers arrived from Mexico for a festival of Mexican Days in Perm, and dance and musical troupes hailing from places from Moscow and Saint Petersburg to Italy and Zimbabwe performed on those same stages on other days. Less than a hundred yards from the folklore performance stage hung exhibits from the Russian Povera art collection in a temporary exhibit space for PERMM.

Every hour or so when the Festival Village was open, teams of two or four young men and women would appear at the tops of the two tall towers that flanked the main entranceway from the Perm esplanade into the Festival Village. Clad all in white and standing in formation, they would raise red semaphore-style flags, one in each hand, and go through series of signals in unison (see fig. 13). The friends and acquaintances with whom I walked through the Festival Village often commented on the flag signals, but, as far as we could tell, there did not seem to be a regular coded message to be deciphered. Less important than decoding precisely what they were signaling, it seems to me now, was the direction in which they signaled. From the highest point in the Festival Village, they looked down Perm's central esplanade, out beyond the Perm-2 railway station, in the direction of Moscow and, beyond that, to the cultural capitals of Europe. Perm, they signaled repeatedly, is here.

On one of the festival days in early June 2012, I attended a public interview with Boris Mil'gram in the Festival Village's club, where he was presented by the interviewer as "one of the main creators of the whole idea of festival life in Perm in the format we see today." In answer to a series of questions, Mil'gram presented the White Nights in Perm Festival as clearly emerging from his life in the "zone of unexpectedness" and creativity that was the world of stage theater. "I didn't always want to change Perm, but it seems to me that theater can change life. ... It's possible to look at the [Festival] Village and believe that we live in an excellent city and that therefore the roads will be repaired and the apartment buildings will change-in that order, and not the other way around." White Nights in Perm was, he said, a "model for life" that, if one

\footnotetext{
${ }^{1}$ Precise state budget figures for the White Nights in Perm festival are hard to come by. Official regional expenses were in the neighborhood of 150 million rubles, but that number is likely quite low as a total budget figure, given the numerous other sources and lines of funding that underwrote the festival's many elements.
} 
believed in it, "could be found all the time" - not just in the summer festival months. But that model for life did not feature much in the way of Russian political figures or political parties - the hundreds of events in the Festival Village were directed, rather, at the creative transformations of individual lives and urban space.

By the organizers' reckoning, over half a million people visited the White Nights in Perm Festival Village in June 2012. Many more attended other associated events and productions nearby, such as a sold out run of Scarlet Sails, a romantic musical that was a White Nights staple in Saint Petersburg. Among my friends and acquaintances, it was clear that a number of skeptics had finally been won over, at least to the point where they-and especially their children - were enjoying the nightly possibilities for strolling and entertainment. "We've gotten used to [the Perm Cultural Project] now . . . even to the crazy public art," said one friend. "Five or six years ago," said another, "there was nowhere to go in Perm . . . and now you can't possibly make it to everything interesting."

\section{Against State Culture}

I returned to the Festival Club tent ten days later for the opening of a workshop for cultural managers from other regions of Russia who had come to network and learn about how to stage large-scale cultural projects. Boris Mil'gram was again one of those welcoming the guests, and, as a way of orienting them, he drew an explicit contrast between the Festival Village and the celebrations of City Day in Perm that had taken place at the other end of the esplanade a couple of days earlier, on Russia Day, June 12. Perm's city administration, he said, had decided that it needed its own separate celebration, one that included more standard and familiar elements: welcoming words from the mayor, a parade of representatives from different city districts, each presenting their district's distinctive characteristics, a subsequent parade of companies and other groups (with Lukoil-Perm's large contingent taking the lead), participation from regional representatives of the United Russia Party, and a long set of musical numbers. Mil'gram pronounced the entire affair "a monstrosity" and continued:

It's just that state power (vlast') wants to present itself, wants to create something around itself. If you just want to present yourself, then why are the people even there? [If that's what you want to do, then] the best way is to do it like Putin. Empty roads, just a camera. Present yourself to the whole country and move on. It's great. Everyone understands. There's the tsar. And even if you do want to add the people in, why would you contaminate the whole thing with such an awful concert when here [in the Festival Village] we have good ones?

This comparison resonates well with similar kinds of statements in the official vision of the Perm Cultural Project. In the understanding of its architects, that is, the Perm Cultural Project, in all its various incarnations and especially in their intersection in the White Nights in Perm Festival, had moved some significant distance from the modes of cultural production that had focused on the legitimation or sacralization of the federal state, whether Soviet-era or Putin-era. ${ }^{1}$ It is certainly useful to understand, as many have, the grand Russian cultural spectacles of these years - up to and including the Opening Ceremonies at the Winter Olympics in Sochi-as contributing to the fetishization of the Russian state and its embodiment in the person of president Vladimir Putin, but we must also acknowledge that these Russia-wide cultural spectacles unfolded in dynamic relationship with many other possibilities, and even cross-currents, at regional and local levels. In the same way that I showed for regional state agencies and regional corporate subsidiaries in previous chapters, the central Russian state apparatus was far from in control when it came to the regional cultural field in Perm and the Perm region. Indeed, many of governor Chirkunov's most vociferous critics wished, at least at times, that the cultural field was more centralized, for they regularly appealed, without success, to the federal Ministry of Culture to shut the Perm Cultural Project down and send Gel'man, Mil'gram, and their colleagues packing. But even these critics, when asked about what they would prefer to see in the sphere of culture, did not wish for more federal projects or more centralization. They sought an alternative sort of region-based cultural production, one that marked its own careful distance from the federal center.

\footnotetext{
${ }^{1}$ In their focus on creativity, entrepreneurship, and economic development, the architects of the Perm Cultural Project also avoided talk of kul'turnost', "culturedness," despite its centrality to Soviet (Kelly, 1999) and post-Soviet (Patico, 2008) discourse. Many people in Perm did talk about the Perm Cultural Project in these terms, but these conversations lie outside the scope of my present argument.
} 


\section{The Cultural Opposition}

In 2009, I ran into an old acquaintance who had spent most of her career working in a Perm museum and asked about what were then the early stages of the Perm Cultural Project. "We have a new minister of culture," she said, "who says that it's his job to make the people of Perm smile." She added acidly: "They'll be laughing soon enough." The most vocal source of discontent with the Perm Cultural Project was what was usually referred to as the "local intelligentsia" - a mixed and shifting set of cultural producers that is more internally diverse and contentious than the label implies (see esp. Fadeeva, 2011). (Not surprisingly, perhaps, those affiliated with Perm's vibrant theater scene were less critical of Boris Mil'gram than, for instance, either the museum workers or music school instructors with whom I spoke.) Although the wide array of artists, writers, and other cultural producers that took up the cause against the Perm Cultural Project had not objected much to the entry of Lukoil-Perm into the cultural field or to the independent Kamwa festivals, the opening of the Perm Museum of Contemporary Art and what they viewed as the takeover of the regional Ministry of Culture by the Perm Cultural Project provoked a sustained response that was vigorously reported by regional newspapers and endlessly debated on blogs and in public forums. Like the European Capital of Culture campaign in Skopje, Macedonia, studied by Andrew Graan, the Perm Cultural Project also "authorize[d] citizens to demand responsible representation and to leverage the branding process to agitate for alternative conceptions of the social order" (Graan, 2013: 165). Unlike the Macedonian case, however, critiques of the Perm Cultural Project were largely about center-region relationships. They also continued to proceed through institutions, languages, and expectations shaped by the regional oil complex.

One of the first and most acrimonious battles came in 2009, and it drew in a number of Perm's most prominent post-Soviet businesspeople, politicians, and cultural producers in ways that illustrate the continuing centrality of various aspects of the regional oil industry to cultural production. Recall that, by the mid2000s, Andrei Kuziaev (of the Perm Commodity Exchange, Perm Financial- Productive Group, and LukoilPerm), Evgenii Sapiro (Perm Commodity Exchange "godfather," former deputy governor, and Lukoil-Perm adviser), and Iurii Trutnev (former governor) had all left their 1990s and early 2000s positions in Perm regional political and economic circles and moved up to the federal level in Moscow- Kuziaev at Lukoil Overseas Holding, Sapiro as his freelance consultant, and Trutnev as Russia's minister of natural resources. In addition to their day jobs in Moscow, the three were among the key members of the Moscow-based Perm Fraternity (Permskoe Zemliachestvo), a network of expatriates from the Perm region who were dedicated to improving the region's image in the capital (and, at the same time, maintaining a hand in regional affairs from afar). In addition to its ongoing center-region networking possibilities, the Perm Fraternity launched a new initiative in 2006: the annual Stroganov Prizes, meant to honor contributions to the life and image of the Perm region in a number of categories, ranging from sport to economic life to culture. Nominations were accepted each year in all categories, with a panel of experts making a recommendation to the leadership of the fraternity. Winners were decided in secret, by an unnamed committee, and awarded the ruble equivalent of $\$ 10,000$ at a gala celebration.

The earliest Stroganov Prizes for achievement in culture and art were uncontroversial. The 2006 prize went to the novelist Aleksei Ivanov for his bestselling and acclaimed The Rebellion's Gold, Or Down the Craggy River, a historical novel based in late eighteenth-century Perm province (and about which more below). In 2007, the prize went to Georgii Isaakian, director of the Perm Opera and Ballet Theater. No prize in the culture category was awarded in 2008. However, following the opening of the Perm Museum of Contemporary Art, the Perm Fraternity announced that the 2009 Stroganov Prize for achievement in the field of culture would be given to Marat Gel'man. The announcement provoked an immediate and intense backlash. Novelist Aleksei Ivanov quickly declared that, if Gel'man were actually awarded the Stroganov Prize, he would return his inaugural 2006 prize in protest. Newspaper editorial pages, local academics, cultural producers, and politicians of all stripes lined up on either Gel'man's or Ivanov's side - the first in a set of running battles that lasted through the end of the Perm Cultural Project years later. In the narrow matter of the Stroganov Prize, Andrei Kuziaev personally brokered a compromise. Ivanov agreed to keep his award in name, but donated his prize money to the Stroganov museum complex in Usol'e. Kuziaev matched his donation with a personal contribution of the same amount. For his part, Gel'man agreed to donate his prize monies to opening a House of Photography in Perm, a project that would be led by Andrei Bezkladnikov, a Perm photographer who was at that time living in Moscow and who Gel'man hoped to woo back to Perm as another element of the Perm Cultural Project. 
The Stroganov Prizes constituted a new arena of cultural competition and distinction in the Perm region. The world of cultural prizes and competitions and their intersection with capitalist sponsors has long been noted in studies of cultural politics inspired by Pierre Bourdieu (e.g., Bourdieu, 1993) and other cultural sociologists, but it was as new to the Russian cultural scene as were Lukoil-Perm's grant competitions in the mid-2000s. It brought with it a new field for cultural debate and competition and a new way in which capitalist corporate as well as state interests intersected in the sphere of regional cultural production, consumption, and evaluation. It is notable, then, that even as Chirkunov's Perm Cultural Project sought new directions for regional culture and economy, some of the key final arbiters of how distinction was allocated hailed, in fact, from the state-corporate field of the previous governor, despite the fact that its key players had been transplanted to Moscow. Even without direct sponsorship, Lukoil- Perm remained a powerful arbiter as the regional cultural field stretched out over the Moscow-Perm axis, and it did so, once again, under the aegis of the Stroganov name.

Echoes of the Russian oil complex were also to be found in the substance of critics' objections to the Perm Cultural Project. One of the chief complaints registered by Aleksei Ivanov and his fellow critics about Marat Gel'man's Stroganov Prize, for instance, was that neither PERMM nor the growing Perm Cultural Project was designed to benefit Perm at all. The evidence for this was to be found in the very nature of Chirkunov's team and the times and places in which they operated. In this view, the Perm Cultural Project was primarily a conduit for Moscow-based culture producers like Marat Gel'man to siphon money out of the regional budget at a time when Moscow was no longer as lucrative a place as it had been in the early 2000s. As Igor Averkiev put it in the opening pages of a lengthy dissection of the Perm Cultural Project published in a regional newspaper and on the Perm Citizens' Chamber's website in late 2009, "Perm has become an attraction for Moscow and international creative types who are bored and broke in the [global] economic crisis. ... [They want] to ride out these crisis years under the administrative and financial wing of Permian power structures." 1

These critics pointed out that the entire project seemed to emerge from a very specific personal network and to come precisely as the mid-2000s Russian oil boom was stalling. Moreover, many of the management contracts for the Perm Cultural Project were going to Moscow-based firms, and most of the artists and performers were not from Perm either. Moreover, after the widely acclaimed and admired Russian Povera exhibit, many residents of Perm told me that subsequent shows at PERMM were second hand (sekond khend) or factory seconds (shtok) - kinds of art that were no longer wanted or appreciated in more prestigious locales like Moscow and were therefore being dumped on an unsuspecting Perm. A traditional focus of the regional Ministry of Culture - the development of new musicians, artists, performers, and cultural managers through a network of local schools and institutes - was suddenly neglected in favor of large, spectacular, expensive, and short-term projects that never seemed to include artists from Perm. The Perm Union of Artists and the Professional Union of Culture Workers were thus in the forefront of the opposition, and they demanded attention to Perm-based artists, artwork, and the schools and institutions dedicated to producing more of them. Gel'man had little patience in response: "Look at the Pinault Museum in Venice or the Guggenheim in New York - are there lots of Venetians and New Yorkers [on display] there?"2

Given all this, and the fact that Chirkunov, Gel'man, Mil'gram, and Gordeev all had preexisting friendships and other ties, it could therefore be deduced that the Perm Cultural Project was the coordinated effort of a network interested in seizing power and profit for its own gain, innovative only in that culture was an unexpected corner of the state budget in which to attempt this. In this view, the Perm Cultural Project was just a new twist on the familiar practice of Muscovite raiding: This time, instead of wealthy Muscovites coming to the provinces in search of privatization deals and companies to acquire when possibilities had diminished in the capital, the raid was taking place on the terrain of culture, which had gone through a similar, somewhat delayed, trajectory of boom and bust in Moscow and whose leading practitioners were looking for new arenas of profit making. Some version of this accusation was quite commonly mentioned to me in conversations with all sorts of friends and acquaintances. Anthropologist Anna Kruglova (personal communication) reported a succinct version to me from one of her own interviews with a Perm-based culture worker:

\footnotetext{
${ }^{1}$ Igor Averkiev, "Permskii Kul'turnyi Puzyr'," part 1, Novyi Kompan'on, September 29, 2009.

"Marat Gel'man Protiv Alekseia Ivanova," Russkii Portret, July 19, 2009. Available at: URL: http://rupo.ru/m/1743/marat_gelyman_protiw_alekseya_iwanowa.html.
} 
[The Perm Cultural Project team] has created a product that has no relationship to reality, but sucks perfectly real money out of the budget. Why is that happening now? Because people have appeared who aren't able to steal metallurgy, but know how to steal culture.

As I learned more about the 1990s raids and deals in the oil sector discussed in previous chapters, I began to try out my own twist on this understanding of events with my interlocutors. This might be a similarity, I would agree, but the difference between the periods was that in the 1990s, a powerful coalition of local business- men and state administration officials stood up to the corporate raiders from big Lukoil, leading to the compromise that produced ZAO Lukoil-Perm and OOO Lukoil-Permneft and retained control over important circuits of regional exchange and their ties to senses of Permianness. This time around, I went on, it seemed as though Perm's cultural producers had no analogous champions in regional business or state administration. It was, in fact, precisely those local officials - Chirkunov and Mil'gram - who allied themselves with the powerful outsiders. Among opponents of the Perm Cultural Project, this was a narrative that entirely fit with their understanding of what was happening; "Yes," one of my interlocutors replied immediately to my framing, "[Chirkunov and Mil'gram] were just kid- napped by those Muscovites." I have noted that that the Perm Cultural Project's architects assiduously avoided what they saw as cultural production that served the legitimating ideological purposes of the state on the model of either the Soviet period or the Putin era. It is interesting that, for the most part, their critics con- ceded this point: there were few objections that the cultural project was glorifying or sacralizing the regional state apparatus or Oleg Chirkunov personally. Instead of seeing state abstractions accomplished by state-led cultural production, critics saw a specific Moscow-Perm coalition pursuing its own interests at the expense of the Perm region as a whole (see also Leibovich and Shushkova, 2011).

To be sure, those on the inside of the Perm Cultural Project disputed that significant money from Perm tax receipts was going to Moscow, emphasizing that the permanent collection at PERMM was being assembled by an array of businesspeople and that even the renovation of the River Station Hall was financed in good part by Senator Gordeev. This was private money serving a public good, they maintained, and, in any case, the long-term economic benefits to the Perm region-whether from other subsidies and sponsorships or a coming culturally focused economic boom - would far outweigh any budget outlays. Culture, they said, remained far and away the cheapest part of the budget in which to encourage economic growth. I have no reliable budget figures to cite that could prove the accuracy of either side; the point, rather, is that many of the debates and conflicts in the cultural field borrowed language, concepts, and expectations that stuck closely to patterns familiar from an earlier epoch of struggles over regional values in a federal system-one that configured oil, regional cultural distinctiveness, and state-corporate alliances in ways both similar and different.

Much the same could be said of another critique of the Perm Cultural Project, an essay called "The Perm Cultural Bubble," by Igor Averkiev, a noted human rights activist and organizer in the Perm region whose writings were widely read by local intellectuals. In this essay, Averkiev argued that the rise of interest in con- temporary art - around the world but especially in Russia - was an outcome of the commodity and speculative booms of the 2000s:

The virtual-speculative economy of financial bubbles and pyramids, which has driven the global economy to today's sorry state, must find its reflection in culture. . . . Contemporary art, like the bubble economy, lives in the airless space of synthetic symbols and thoughts, where real "consumer prices" are determined not by objects, images, and feelings, but by opinions about them, or more accurately, "the status of opinions in the system of opinions." "The virtual economy" and "contemporary art" are, in fact, both speculative constructs. . . In any speculative model, the consumer is an insubstantial figure, because the "market operators" have found a way to manipulate the continuum of supply and demand to their own ends (remember the pre-crisis history of oil prices). . . The price of culture (in the sense of fine arts) in Perm is now overstated and must collapse, just like oil prices, and with the same consequences. ${ }^{I}$

\footnotetext{
${ }^{1}$ Igor Averkiev, "Permskii Kul'turnyi Puzyr'," part 2, Novyi Kompan'on, October 6, 2009. Averkiev uses the term aktual'noe isskustvoe rather than sovremennoe isskustvo; although specialists.
} 
Although the article is without footnotes or other references, this element of Averkiev's critique belongs to a family of approaches to culture and finance capital taken by a number of Marx-influenced scholars, among them Frederic Jameson, who writes that "the problem of abstraction-of which this one of finance capital is a part - must also be grasped in its cultural expressions" (Jameson, 1997: 252). The Retort collective, drawing on Guy Debord's famous dictum that "the spectacle is capital accumulated to the point where it becomes an image" (Debord, [1967] 1977: 34), likewise posits a newly salient relationship between accumulation strategies in and around the global oil industry and a newly intense, highly abstracted, "battle for the control of appearances" (Retort, 2005: 31) that was central to the attacks of September 11, 2001, and the ensuing U.S. War on Terror.

I am less concerned with whether these ways of linking oil and images of various sorts are, in general germs, analytically accurate than with drawing attention to the ways in which this brand of critique was deployed in the context of Perm's ongoing cultural upheavals. Averkiev's critiques of conceptual art as a speculative system and his invocations of pyramid schemes and fluctuating oil prices, like criticisms of PERMM as an instance of culture raiding, are notable because they extended into a new era the kinds of regional debate over the relationship between oil and Permianness that began in the early 1990s with petrobarter chains and fuel veksels and moved to Lukoil-Perm's CSR projects and state-run grant com- petitions in the early 2000s. In all these cases, materiality and abstraction, region and center, and Permianness and nonPermianness formed the grid on which claims and counterclaims were made about what it meant, and what it should mean, to live in the Perm region. Moreover, various elements of the regional oil complex continued to inflect regional sensibilities - it was on this grid that the Perm region continued to be fashioned as an oil region, even by those who sought other paths for it.

\section{Landscapes, Matrices, Spines: Aleksei Ivanov's Urals}

Averkiev's "Perm Cultural Bubble" begins by noting that even if some of the projects on which Chirkunov's team had embarked were attractive and welcome, the Permian land (Permskaia zemlia) was "not native [rodnoi] to them. . . . They just use it, and sometimes trample it." The essay winds down on a similar point, noting that if Oleg Chirkunov had been governor of any other region, that region would have become Russia's next aspiring cultural capital. That is, if The Perm Project was a region-based challenge to the center, it had nothing to do with the Perm region in particular, and that was the problem: "They don't care where - they are indifferent to the place on the map. But we are not indifferent." Averkiev went on to argue for a kind of contemporary change that was place-based: "The world is changing in different waysnot only in globalization but also in the rap- idly growing regionalization of national territories. New and mighty regional centers are forming everywhere." 2

In fact, the "Perm Cultural Bubble" opens not only with critique, but with a grudging, "Thanks for the Summons"- a summons to help imagine a place for culture in the Perm region different from that proposed by Chirkunov and his team. Nearly all opponents of the Perm Cultural Project had a long list of counterproposals for the development of culture in the region, and, indeed, claimed that regional cultural producers had long been at work on them only to have their efforts interrupted and diverted by the Perm Cultural Project (see, e.g., Karzarinova and Abashev, 2000; Nikitina, Ustiugova, and Chernysheva, 2001). Perm Animal Style as a brand, the independent Kamwa festivals, and the field of "Permistika" as explored by V. V. Abashev and collaborators based at Perm State University (e.g., Abashev, 2008) were all cited to me as region-based alternatives. The most popular alternative, however, was a set of cultural projects proposed by novelist and culturologist Aleksei Ivanov. Academics I met referred me to Ivanov's culturological essays (often enough with warnings about their historical accuracy), librarians slipped his work into my hands when I asked about contemporary regional studies, and he also edited a series of books and collections called Perm as Text that brought together region-based fiction and nonfiction by a range of authors. Ivanov's numerous novels, which had gained local and national fame even before the Perm Cultural Project began, were always prominently on display in Perm's bookstores. I focus on projects associated with Ivanov because they were perhaps the most widespread, in part due to his sheer productivity and in part due to his willingness to engage in frequent, public, and contentious disputes with Chirkunov's team.

\footnotetext{
${ }^{1}$ Averkiev, "Permskii Kul'turnyi Puzyr'," part 1.

${ }^{2}$ Igor Averkiev, "Permskii Kul'turnyi Puzyr'," part 3, Novyi Kompan'on, October 13, 2009.
} 


\section{Regional Magical Historicism}

Aleksei Ivanov was born in 1969 in Nizhnii Novgorod, but his family moved to the Perm region in 1971, and he eventually studied journalism at Urals State University. He worked as a tour guide and local historian on the Chusovaia River in the Perm region between 1992 and 1998, and many of his later projects featured careful, detailed descriptions of rivers, mountains, and landscapes of the Perm region that he had come to know intimately. Ivanov's first novel, released to significant critical acclaim in 2002, was Heart of the Uplands (Ivanov, [2002] 2012), set in and around fifteenth-century Cherdyn, capital of Perm Velikaiathe Principality of Great Perm, a Komi-Permiak feudal state in what is now the north of the Perm region. The novel traces the bloody and ultimately unsuccessful effort by the Permian Prince Mikhail to resist annexation by Ivan III, grand prince of all the Rus (known to historians as "gatherer of Russian lands" and founder of the Russian state). ${ }^{1}$ Heart of the Uplands tells the historically familiar story of annexation and early Russian state formation largely from the perspective of the annexed, including Komi and Mansi tribes, their warriors and shamans, and indeed the Permian lands themselves. We learn in the book's very first pages, in a scenesetting conversation between a warrior prince and a shaman, that the Rus-Novgorodians have come "because they want our riches . . . and in addition to our treasures they also want all our land" (Ivanov, [2002] 2012: 16). Ivanov's The Rebellion's Gold, or Down the Craggy River (Ivanov, [2006] 2012), published in 2006, takes place almost entirely on and around the Chusovaia River in the immediate aftermath of the chaos and confusion that followed the Pugachev Rebellion of 1773-74; its protagonist is a river barge operator searching for gold stolen by Pugachev. This novel, too, is about the reestablishment of central Russian state power in the wake of disorder and challenges to state sovereignty.

Ivanov's work can certainly be read as a commentary on Russian life after the parcelization of sovereignty and chaos of the 1990s (Kukulin, 2007). The main character in The Rebellion's Gold is, after all, nicknamed Perekhod- "transition." As Ivanov frequently recounted in media interviews at the time, Heart of the Uplands, too, could be read as a critique of the reemergence of central Russian state power in the late 1990s and early 2000s. This was not necessarily what he set out to write, Ivanov claimed, but, given the centuries-long historical pattern in which Muscovites come to the Perm region in search of land and riches for themselves, it could hardly have been otherwise. With these novels already popular in the region, Ivanov had a ready-made critique of Chirkunov's team that he did not hesitate to deploy far and wide: the precedents for Muscovite raiding of Perm and Permian cultural distinctiveness went back centuries, and were foundational to the establishment of the Russian state. The Gordeev-Gel'man raid was a story as old as Russia itself.

But Ivanov's novels captured regional imaginations for reasons other than historical analogy to present-day patterns of state formation. His books are filled with lengthy, detailed descriptions of the landscape, especially of the rivers and mountains of the Perm region that Ivanov himself came to know so well through his own travels. His characters often reflect on the entwined nature of humans and their surroundings, and he borrows liberally from the mythologies of Finno-Ugric tribes to create and animate otherworldly actors. Spirits and witches, gods and demons, and enchanted objects are everywhere in his pages-participants in the battles, tempters and lovers of the protagonists, and casualties of Russian Orthodox missionaries. Perm-based literature scholars and semioticians V. V. Abashev and M. P. Abashev (Abashev and Abashev, 2010), in fact, see Ivanov primarily as a poet of the landscape, drawing on Roman Jakobson, Rudolph Otto, and a long Russian literary tradition to show numerous ways in which the materiality of the Perm region itself participates in the action of the novels.

Ivanov's novels, wrote one of his popular press interviewers, "turned Perm into a magical land with a living history." 2 The mystical inhabitants of Ivanov's novels are not alone in contemporary Russian literature, where they find good company with the supernatural Others and vampires of Sergei Lukianenko's Night-watch series (e.g., Lukianenko, 1998; 2000), the time-traveling werewolves and werefoxes of Viktor Pelevin's The Sacred Book of the Werewolf (Pelevin, 2004), and numerous other tales of the undead, the resurrected, or the quasi-human. ${ }^{3}$ Alexander Etkind (Etkind, 2013: 220-42) has appropriately termed this writing magical historicism to distinguish it from the magical realism of postcolonial literature and situate it in

\footnotetext{
${ }^{1}$ Heart of the Uplands was actually the second of Ivanov's major works, but his first, The Geographer Drank Away His Globe (Ivanov, 2005) (later made into a major movie filmed in the Perm region), did not find a publisher until after the success of Uplands.

${ }^{2}$ Konstantin Mil'chin, "Rossia: sposob sushchestvovaniia," Russkii Reporter 39 (167), October 10, 2010.

${ }^{3}$ The Perm region is not the only oil region visited by such quasi-human beings and forces on the field of cultural production; see Atkinson 2013 on vampires and the United States Gulf Coast in the wake of BP's Deepwater Horizon oil spill.
} 
the specificities of the post-Soviet moment. Against this backdrop, Ivanov's work is remarkable in part because its magical historicism is relentlessly regional, laboriously carved into the landscape of the Perm region. The world conjured in Ivanov's texts is, moreover, to be encountered not only between the covers of a bestseller, but also through river tours, festivals, new museums, and extreme sports - all projects in the Perm region in which Ivanov was personally engaged, all projects that unfolded, at least in 2009-12, as parts of an explicit challenge to the abstractions of Chirkunov's Perm Cultural Project. ${ }^{1}$

After the success of Heart of the Uplands, for instance, Ivanov worked with the district administration in the Cherdyn district of the northern Perm region to host a large and successful series of outdoor festivals by the same name in 2006-9. The festivals attracted many thousands of guests, who were treated to all manner of games and events drawn from the era described in the book. The festival's name was later changed to The Call of the Uplands: An Ethno-Landscape Festival, and began to attract many of the same young people as the Kamwa festivals - nearly twenty thousand of them in 2011. Indeed, Ivanov himself was an occasional con- tributor to Kamwa projects (see Ivanov, 2008) and some of the Kamwa organizers I met expressed their hope that the new festivals with historical themes picked up from Ivanov's novels would replace the Kamwa festival as it wound down.

\section{“The Urals Matrix" and Ivanov's Cultural Projects}

In 2008, Ivanov began supplementing his fiction with a series of culturological essays, the most widely known of which was called "The Urals Matrix" (Ivanov, 2009). These essays lay the groundwork for The Spine of Russia, a major television series and accompanying large-format book of photographs and text (Ivanov, 2010a; 2010b). The overarching claim of these culturological projects - the closest there was to an explicit countermanifesto to the Chirkunov team's The Perm Project-was that the Urals region presents a sui generis configuration of many elements, both natural and human - a matrix. This matrix has structured and informed life in the Urals, including in the Perm region, for centuries, and it can be traced explicitly from to the present day back to the time of Ermak, whose famous sixteenth-century expeditions "opening" Siberia were launched from Perm. The term "matrix" itself is indicative of the kind of history that Ivanov wants to project. In the first place, this history is, in keeping with the original Latin meaning of matrix, generative: it gives birth repeatedly across the centuries to a particular and identifiable lineage of complex forms - political, economic, social, and cultural. Matrix is also appropriate because of the term's long history of use in paleography and geology, where it indicates the rocks onto which fossils attach themselves, and metalworks of various sorts - from industrial stamping to the casting of figurines. The long geological history of the Perm region, along with its deposits of salt, potash, coal, copper, oil, and the mines, factories, and factory towns that have grown up to exploit them, are at the heart of Ivanov's vision of the Urals as a mining civilization.

In Ivanov's view, several elements and characteristics of this matrix recur throughout history in new configurations - a result of enduring landscapes and, to no small extent, enduring mentalities. The Urals have always been, and continue to be, a meeting place of difference: between Europe and Asia, among Christianity and Islam and paganism. The "genetic code" (Ivanov, 2010a: 201) of this matrix is the landscape of the Urals itself: its rivers, mountains, mineral deposits, and the ways that all these elements channel and enable the movement and organization of human settlements. The meetings that take place on this landscape, Ivanov argues, lead to personal and historical transformations that have recurred again and again in the history of the Urals. The mixing of Finno-Ugric paganism and Christianity, for instance, yielded the Permian gods, hauntingly beautiful wooden sculptures of Christ, now housed in the Perm State Art Gallery, that are quite specific to the Perm region and exceptional because sculpted images of the divine are generally not permitted in Eastern and Russian Orthodoxy. Another recurrent theme in the history of the Urals is expansive local sovereignty: the tendency for industrial leaders to strike deals with central power that create domains of power within domains of power (derzhava $v$ derzhave). The Stroganov and Demidov families, both of which had special concessions from the tsar for their factories and other operations in the Urals, are the archetypal cases of this expansive local sovereignty. The 1990s-2000s privatization schemes and oligarchs of the postSoviet period, in Ivanov's view, are their most recent incarnations.

Especially in the popularizations of Ivanov's perspectives on the Urals that make up The Spine of Russia, the point of attending to the Urals matrix in this way is to convince the viewer/reader to understand

\footnotetext{
${ }^{1}$ On Ivanov's novels and cultural projects as a seamless whole and part of a larger effort to seek out the "cultural-symbolic selfdetermination of Russian territories," see Abashev and Firsova, 2013.
} 
not just the Urals, but all of Russia differently. Ivanov argues that it was in the Urals that Rus became Russia- it was through Ermak's encounters in the Urals, he notes, that the famous explorer turned from raiding brigand into settler in the service of the tsar. We find out, in fact, that many firsts were accomplished in the Urals: the samovar was actually invented in the Urals; the first steam engine was produced in the Urals (although its importance and potential were not recognized by its builders); Russian business started in a small (now abandoned) accounting office; Russian fairy tales owe many of their characters and plots to the myths of the old Perm region, including those associated with Perm Animal Style. The first island in the Gulag Archipelago, too, is to be found in the Urals. All these firsts are the children of the Urals matrix, the precipitate of centuries' worth of encounters and entanglements on the landscapes of the Urals. They are the contributions, good and bad, of the Urals region to larger Russian history and identity. This combination of identity, distinctiveness, and generativity is, Ivanov insists, premised on the provinciality, the noncentrality, of the Urals within Russia. It is, in his view, because the Urals are a meeting place, and have been for centuries, that so many innovations and departures in Russian history can emerge here. To declare that a capital of anything might be found or constructed in the Urals is, therefore, precisely to miss the importance of the Urals as noncentral and peripheral. This was the point that Ivanov again and again drove home in his public and vocal opposition to Chirkunov's European Capital of Culture campaign.

Academic historians of the Perm region have not always agreed with the details and particulars of Ivanov's historical and culturological analyses; in my own view, they surely attribute too much to mentalities and abstract, underspecified historical and personal forces that can explain any and all things. As I noted in the introduction, they clearly neglect local historical consciousness. It is, nevertheless, in good part because of its sweep and ability to tell a new and coherent story about the Urals, one discoverable in the landscapes of the Perm region, that Ivanov's work gained such a following and spread across so many platforms. Survey research by Abashev and Firsova (Abashev and Firsova, 2013) revealed that 25 percent of the residents of Cherdyn had read Ivanov's Heart of the Uplands, set five centuries earlier in their hometown, and 81 percent had participated in one way or another in the eponymous festival that Cherdyn began hosting in 2006. Nearly 35 percent of surveyed travel agents in the Perm region agreed that Ivanov's work had significantly and positively influenced the image of the Perm region among tourists.

For all his disagreement with the Perm Cultural Project, though, Ivanov's corpus of works ended in a similar place: for the postindustrial Perm region, he believed, marketing cultural brands and historical distinctiveness was the way forward. ${ }^{1}$ Ivanov was not, however, much of a supporter of folk handicrafts production and fairs in the manner of Lukoil-Perm. His proposed answers also include tourism, but tourism of the sort that includes river tours, outdoor sports, and long hikes that pass through old factory towns. One of the three main hosts for the television-series version of The Spine of Russia is Iulia Zaitseva, an extreme sports enthusiast. The historical excursions and commentaries provided by Ivanov and journalist host Leonid Parfenov are interspersed with Zaitseva demonstrating the ways in which tourists might experience the Perm region and the larger Urals. After Parfenov and Ivanov discuss and trudge along one of the imperial-era roads running through the Perm region, for instance, Zaitseva notes that it is easiest to traverse these roads these days in a four-wheeler, and we see her churning through the mud. Zaitseva shoots rapids in a catamaran, climbs towering factory smokestacks in the latest mountaineering gear, views archaeological sites from a hot-air balloon, and drives a tunneling machine through salt mines. The series concludes with the trio passing an old factory town, which Ivanov informs viewers is in the process of becoming a dacha settlement-a place used for leisure rather than work. Leisure, he says, is the latest trend for the Urals as a whole.

Ivanov himself had been engaged in a multiyear effort to turn the old town of Kyn, in the Lys'va district, into a new tourist destination. He helped win the designation of Perm Regional Cultural Center for Kyn in 2010, and, in the same year, opened the tourist program Kyn-Reality that combined lessons in the history of Kyn as an exemplary Urals factory town with rafting excursions on the Chusovaia River in the summer or snowmobile excursions in the winter. In his public disputes with the Perm regional administration, Ivanov often held up Kyn as an alternate model of regional cultural development for tourism, one that would benefit

\footnotetext{
${ }^{1}$ On other nation- and culture-branding efforts in the postsocialist world, see Dzenovska, 2005; Jansen, 2008; and Marat, 2009. My analysis here has its closest kinship with Manning and Uplisashvili, who write that, "Brands, like the commodities they are attached to, are material semiotic forms whose circulation defines a broader social imaginary, . . . whether it is the market, the nation, or the empire that in part gives them meaning" (2007, 628; internal reference omitted).
} 
the region rather than the federal center and would provide tangible infrastructural benefits right awayespecially a new road linking Perm and Sverdlovsk-to handle increased tourist traffic.

\section{Ivanov's Oil}

The production and refining of oil occupies a minor place in Ivanov's conceptualization of the Urals: among the many items emerging from the subsoil charted in "The Urals Matrix" and the television version of The Spine of Russia, oil is not mentioned directly - either in its discovery in the twentieth century or its contemporary significance. There is a single page devoted to oil production in the book version of The Spine of Russia, and it deals with the Republic of Bashkiria, further south of the Perm region in the Volgo-Urals oil basin. Indeed, it is not especially clear where oil fits into the model of "mining-metallurgical civilization" that Ivanov outlines; the section on Bashkiria only situates oil in relationship to the broader dynamics of the Urals matrix in one way-by noting that, in Bashkiria, oil became the resource around which the proposal for a sovereign Bashkortostan was floated in the 1990s.

Strikingly, however, oil does feature in another way-in its circulation through the Urals and the Urals matrix as oil, rather than as money. Early on in the television version of The Spine of Russia, at the end of a discussion of the sixteenth- century trading routes that formed one element of the Urals as a meeting place at the time, the following exchange takes place between Parfenov and Ivanov:

Parfenov: It turns out that sable coat was our barrel [i.e., unit of mea-sure] of the sixteenth century. Ivanov: Yes, it was a natural currency of that epoch. There were four in all.

Parfenov: So, Russian furs, American gold...

Ivanov: . . Chinese silk, Indian spices. That is, furs were the oil of the sixteenth century.

The illustration on the screen at this point is as significant as the dialogue. It is a colorful ink drawing by Moscow-based artist Il'ia Viktorov, a frequent collaborator of Parfenov's, that depicts Russian traders posing proudly next to a wooden barrel overflowing with sable coats. Above the pair and their barrel, in block letters, is the word "fur"; in stylized lettering and ornamentation on a gold banner below, the words "oil of the sixteenth century" appear.

A later segment of the film employs a similar strategy. In a discussion of the ironworks of the imperial era, a time when, Ivanov argues, the Urals became the blast furnace of world civilization, the film discusses the intricate system by which cannons and other products produced in the factories of the Stroganovs and Demidovs made their way to the rest of Russia. In the winter, iron products were stacked at docks along the Chusovaia River, waiting for the spring thaw, when they would be loaded onto wooden barges. After the ice had cleared from the river, and spring melting had raised water levels, a series of artificial ponds near factory towns was released into the river in a carefully orchestrated sequence. The combination of melting snow and released pond water created a rolling flood that sent scores of heavily laden barges careening along the Chusovaia to central Russia.

Parfenov explains this system to the viewer via analogy to the circulation of oil in the present day: "If you compare a factory to an oil well, then the Chusovaia River is a pipeline, and the dock is a valve. Whoever sits on the pipe and turns the valve rules over all." The visual accompanying this comment is another Viktorov ink drawing, this one showing the Chusovaia River snaking through the Perm region. The river, though, is encased in a pipeline (see fig. 14). In the foreground, the top half of the pipeline is cut away, revealing barges stacked with iron products passing through a large valve, with a massive horizontal on-off wheel atop it. At the valve sits an unidentified Russian noble in full fur and boots and hat, Gulliver- sized by comparison to the barges and people, slowly cranking the wheel as the barges float through on their way west to Moscow. Once again, the Russian nobles of the old Perm region are reincarnated as oil magnates.

Two things are significant about these images of oil in the television version of Ivanov's The Spine of Russia. First, the exchange and circulation of oil is the background assumption, the terms in which other aspects of history - the fur trade or barge transport — can be best explained to a wide television audience. Fur is the oil of the sixteenth century; river transport by barge is the oil pipeline of the Stroganov era. There could scarcely be a better indication, I think, of the ways in which images and vocabularies from Russia's oil complex have worked their way into everyday discourse about history and culture. Second, circulating oil is presented not as abstracted circulating money, but as a natural currency and as a specific, material, regionally produced object under the control of a local notable and moving through the landscape of the Urals. The 
1990s era of pervasive petrobarter exchanges crisscrossing the Perm region may have faded by 2010, but when The Spine of Russia reached for a way to showcase the distinctiveness of the Perm region in the context of the Russian federal state over the long term, it arrived in a familiar place: the nonmonetized exchange and specifically Permian characteristics of oil. ${ }^{1}$

$$
* * *
$$

The chapters of part III have traced a cultural field shaped in significant part by the political economy of the Russian oil complex at a regional level, a field in which the low-labor, high-profit, highly spatialized nature of the oil industry, along with the material properties and transformational potentials of that complex - and of oil itself-again and again had crucial implications for cultural projects and possibilities. Lukoil-Perm's Connections with Society Division, other energy sector and independent cultural projects, Governor Chirkunov's Perm Cultural Project team, and the many projects of Aleksei Ivanov and his fellow travelers all sought to put the Perm region on the map of Russia and the world. They disagreed vehemently about how to do so, but they were all in- habitants of an institutional, discursive, and material field that was powerfully shaped by the oil complex of twenty-first-century Russia.

Oleg Chirkunov resigned his post as governor of the Perm region in April 2012, and even as I walked through the White Nights in Perm Festival Village that summer, word was circulating that the Perm Cultural Project would quickly wind down without its chief cheerleader. Speaking with an employee of the Perm Museum of Contemporary Art one day in 2012, shortly after Chirkunov's resignation, I asked whether Lukoil-Perm would ever sponsor an exhibit at the museum, perhaps stepping in to help if state funding dried up under the next governor. "No," she replied, using the familiar lexicon of depth, oil, space, and cultural production:

Lukoil completely distances itself from us. Lukoil supports only that which relates to classical [art]. It's a resource economy, you understand . . . it's to their advantage to support Ivanov, who mythologizes the subsoil and says: what a magical subsoil (volshebnyi nedr) we have, how sacred it is, how deep and beautiful our roots are. We [at PERMM] say nothing about the subsoil, [but for Lukoil-Perm] it's all roots, roots, especially when they rot through and turn to oil.

At the recent inauguration of Oleg Chirkunov's successor, she went on to say, rolling her eyes, that, she had heard, Aleksandr Leifrid, head of Lukoil's operations in the Perm region, had presented the new governor with a painting - a classical landscape. But I found out later that her information was wrong. The gift was, in fact, a handcrafted item made by one of the company's sponsored folk artisans from an oilproducing district. It was a wood carving of several items that, together, were meant to represent the Perm region - a container labeled "Permian salt," a cannon (for the defense sector), and a barrel (for all other products). Standing behind these three items as if to present them, and nearly twice their size, was a rotund, smiling, bearded, big-eared figure in a peasant shirt - the folk archetype of the jolly, welcoming, simple Russian peasant man. He wore a Lukoil hard hat. As nearly all my interlocutors predicted that summer, the Perm Cultural Project did indeed end quickly. The 2013 White Nights in Perm Festival (already planned and budgeted in 2012) was scaled back considerably and, by the summer of 2014, it had disappeared from the central esplanade entirely. Mil'gram himself returned to more traditional theater directing in 2012, and, a year later, Marat Gel'man resigned his post as head of the Perm Museum of Contemporary Art. In 2014, PERMM moved to smaller and less central quarters on Gagarin Boulevard, where it continued to host exhibits and, on a less grand scale, sponsor and maintain public art projects. As was the case with Governor Trutnev's Capital of Civil Society initiative, then, the effort to fashion Perm into a European Capital of Culture did not outlast the political network that championed it. Chirkunov's critics initially rejoiced at the fracturing of his network and its signature project, and more homegrown cultural projects like the Kamwa festival began to plan and stage a new series of cultural events and spectacles. However, at least some of Chirkunov's critics soon found that they had received more attention - in the media and for their own preferred styles of cultural pro-

\footnotetext{
${ }^{1}$ Alexander Etkind (Etkind, 2011) argues that Russia's ancient fur-based and more recent oil-based economies are similar in that they both led to a resource curse. Ivanov and Parfenov's analogy, I believe, operates very differently, running as it does through the materiality of oil/fur in their regional locations rather than through their accumulation as money in a federal center.
} 
duction - when they were in the midst of high-stakes debates rather than when culture was relegated to its more usual subordinate station.

Chirkunov's replacement as governor, Viktor Basargin, was new to Perm. A native of the neighboring Sverdlovsk region, he had risen through the Party ranks, spent time in the central offices of the Urals Federal District (which, recall, did not include the Perm region) and, from 2008 to 2012, served in Russian president Medvedev's administration as minister of regional development. Basargin's leadership team in Perm was a mix of his own loyal deputies brought in from Moscow and Perm regional powerbrokers from Chirkunov's and Trutnev's teams. In the early years of his term, local elites and outside observers debated frequently whether a new, coherent regional agenda - an effort on the order of those that defined his predecessors' terms to put this provincial region on the map - would emerge out of this three-way hybrid. What was not in dispute, however, as that inaugural gift bespoke so clearly, was that Lukoil-Perm stood ready to serve as general partner of the governor's office, through the same structure of agreements, projects, and initiatives that it had begun nearly two decades earlier. One of Basargin's first initiatives in the social sphere, for instance, was to build and refurbish kindergartens in Perm and throughout the region. Lukoil- Perm was an early and enthusiastic collaborator, and pictures of Lukoil-Perm general director Leifrid and Governor Basargin surrounded by happy school- children quickly became standard fare in the regional media. The company's 2013 signed agreement with the Perm region promised 820 million rubles for development projects in oil-producing districts.

The beginning of Basargin's term also coincided with the return of Vladimir Putin to the Russian presidency in 2012 and, in the wake of the street protests that accompanied Putin's election bid, another round of efforts to centralize power through federal mandates and projects. But there was little sign that the center- region dynamics and frameworks I have traced in this book were set to change dramatically. Responding to President Putin's designation of 2014 as a Year of Culture, for instance, Lukoil-Perm announced Routes of Culture, a special category of social and cultural project grants that would celebrate the eighty-fifth anniversary of Permian oil and showcase the distinctiveness of the Perm region's many cultures and traditions. Central initiatives were once again being routed through regional political and economic networks, landscapes, and sensibilities - as they had been in the postsocialist 1990s, in the socialist Second Baku, in the Stroganov era, and, at least according to widely circulating versions of regional history, long before that.

\section{References}

Абашев, В. В. (2008) Пермь как текст. Пермь в русской культуре и литературе XX века. Пермь: Звезда. [Abashev, V. V. (2008) Perm as text. The city of Perm in the Russian culture and literature of the 20th century [Perm' kak tekst: Perm' v russkoi kul'ture i literature XX veka]. Perm: Zvezda Publ. (In Russ.)].

Абашев, В. В., Абашева, М. П. (2010) 'Поэзия пространства в прозе Алексея Иванова', Сибирский филологический журнал, 2, сc. 81-90. [Abashev, V. V., Abasheva, M. P. (2010) 'Poetics of space in the works of Alexey Ivanov' [Poeziya prostranstva $\mathrm{v}$ proze Alekseya Ivanova], Siberian Journal of Philology, 2, pp. 81-90. (In Russ.)].

Bourdieu, P. (1993) The Field of Cultural Production. New York: Columbia University Press.

Debord, G. (1977) Society of the Spectacle. Detroit, MI: Black and Red.
Produced by Ivanov, A., Parfenov, L., and Zaitseva, Yu. Studiya "Namedni" and Prodyuserskii Tsentr "Iyul"'. (In Russ.)].

Jameson, F. (1997) 'Culture and Finance Capital', Critical Inquiry, 24 (1), pp. 246-65.

Казаринова, Н. В., Абашев В. В. (2000) Искусство Перми в культурном пространстве России. Век XX. Верещагино: Печатник. [Kazarinova, N. V., Abashev, V. V. (2000) The art of Perm in the cultural space of Russia. 21st century [Iskusstvo Permi v kul'turnom prostranstve Rossii. Vek XX]. Vereshchagino: Pechatnik Publ. (In Russ.)].

Кукулин, И. (2007) 'Героизация выживания', Новое литературное обозрение, 86, сс. 302-330. [Kukulin, I. (2007) 'Heroization of survival' [Geroizatsiya vyzhivaniya], New Literary Observer, 86, pp. 302-330. (In Russ.)].

Лейбович, О. Л., Шушкова, Н. В. (2011) 'Чужие игры ...: социальный анализ Пермского 
Fadeeva, L. A. (2011) 'Identity Politics and Interaction between Authorities and Society: The Case of Perm' in: Paper Presented at Association for Slavic, East European, and Eurasian Studies Conference, November 17-20, 2011, Washington, DC.

Graan, A. (2013). 'Counterfeiting the Nation? Skopje 2014 and the Politics of Nation Branding in Macedonia', Cultural Anthropology, 28 (1), pp. 161-79.

Иванов, А. (2012) Сердие Пармы, или Чердынь княгиня гор. Санкт-Петербург: Азбука. [Ivanov, A. (2012) The heart of Parma, or Cherdyn, the princess of mountains [Serdtse Parmy, ili Cherdyn' - knyaginya gor]. St. Petersburg: Azbuka Publ. (In Russ.)].

Иванов, А. (2012) Золото бунта, или Вниз по реке теснин. Санкт-Петербург: Азбука. [Ivanov, A. (2012) The gold of the rebellion, or Down the river gorges [Zoloto bunta, ili Vniz po reke tesnin]. St. Petersburg: Azbuka Publ. (In Russ.)].

Иванов, А. (2008) 'Точка отсчета - Земля', Альманах Камва, сc. 86-88. [Ivanov, А. (2008) 'Reference point - Earth' [Tochka otschetaZemlya] in: KAMWA: Almanac [KAMWA: Al'manakh]. Perm, pp. 86-88. (In Russ.)].

Иванов, А. (2009) 'Уральская матрица: культурологические очерки' в: Пермистика / под ред. А. Иванова. Пермь: Звезда, сс. 241-349. [Ivanov, A. (2009) 'Ural matrix: cultural essays' [Ural'skaya matritsa: kul'turologicheskie ocherki] in: Ivanov, A. (ed.) Permistika [Permistika]. Perm: Zvezda Publ., pp. 241-349. (In Russ.)].

Иванов, А. (2010а) Хребет России: герои, заводы, мастера, матрииа. Санкт-Петербург: Азбука-Классика. [Ivanov, А. (2010a) The Ridge of Russia: heroes, factories, masters, matrix [Khrebet Rossii: Geroi, zavody, mastera, matritsa]. St. Petersburg: AzbukaKlassika Publ. (In Russ.)].

Иванов, А. (2010b) 'Хребет России': документальный фильм, части 1-4 (продюсеры А. Иванов, Л. Парфенов и Ю. Зайцева). Студия «Намедни» и Продюсерский центр «Июль» [Ivanov, А. (2010b) 'The Ridge of Russia': a documentary, parts 1-4 ["Khrebet Rossii": documental'nyi fil'm, chasti 1-4]. культурного проекта', Вестник Пермского государственного института искусства и культуры, 12, сс. 80-90 [Leibovich, O. L., Shushkova, N. V. (2011) 'Other people's games ...: social analysis of the Perm cultural project' [Chuzhie igry ...: sotsial'nyi analiz Permskogo kul'turnogo proekta], Vestnik Permskogo Gosudarstvennogo Instituta Iskusstva i Kul'tury, 12, pp. 80-90. (In Russ.)].

Лукьяненко, С. (1998) Ночной дозор. Москва: ACT. [Luk'yanenko, S. (1998) Night watch [Nochnoi dozor]. Moscow: AST Publ. (In Russ.)].

Лукьяненко, С. (2000) Дневной дозор. Москва: ACT. [Luk'yanenko, S. (2000) Day watch [Dnevnoi dozor]. Moscow: AST Publ. (In Russ.)].

Никитина, О. В., Устюгова, В. В., Чернышева, Н. М. (2010) Периферийность в культуре XX века. Пермь: Пермский государственный университет. [Nikitina, O. V., Ustyugova, V. V., Chernysheva, N. M. (2001) Periphery in the culture of the 20th century $[\mathrm{Pe}$ riferiinost' v kul'ture $X X$ veka]. Perm: Perm State University Publ. (In Russ.)].

Пелевин, В. (2004) Священная книга оборотня. Москва: ЭКСМО. [Pelevin, V. (2004) The sacred book of the werewolf [Svyashchennaya kniga oborotnya]. Moscow: Eksmo Publ. (In Russ.)].

Пермский музей современного искусства «ПЕРММ» (2011) 'Искусство в городе: общественно-художественная программа', Пермь, 2008-2011. Каталог. [Perm Museum of Contemporary Art (PERMM). "Art in the city: public art program", Perm, 2008-2011. Catalogue [Permskii musei sovremennogo iskusstva "PERMM". "Iskusstvo $v \quad$ gorode: obshchestvennokhydozhestvennaya programma", Perm, 2008-2011. Katalog] (2011). Perm: PERMM Publ. (In Russ.)].

Retort (2005) Afflicted Powers: Capital and Spectacle in a New Age of War. London: Verso. 


\title{
Информация об авторе
}

Роджерс Дуглас - PhD (University of Michigan), профессор антропологии Йельского университета (США). E-mail: douglas.rogers@yale.edu (ORCID: 0000-0002-6607-8404. ResearchID: V-75702018).

Статья принята к печати: 30.04.2019

«БИЛЬБАО НА КАМЕ»? ПЕРМСКИЙ КУЛЬТУРНЫЙ ПРОЕКТ И ЕГО КРИТИКИ (ЧАСТЬ 2)

\author{
Д. Роджерс \\ Йельский университет (США)
}

\begin{abstract}
Аннотация
Предлагаемый текст - вторая часть гл. 8 книги Дугласа Роджерса «The Depths of Russia: Oil, Power, and Culture after Socialism» (Cornell University Press, 2015). Первая часть опубликована в предыдущем номере журнала. Рецензия на книгу была опубликована в журнале в 2017 г., №2. Книга Дугласа Роджерса - замечательное исследование «Пермского культурного проекта», одного из самых значительных событий в региональной политике в 2000-е гг. Поэтому мы публикуем этот текст с любезного разрешения автора и издательства.
\end{abstract}

Ключевые слова: культурная политика; искусство; нефть; бизнес и политика. 